Brit. J. industr. Med., 1962, 19, 134.

\title{
METABOLISM AND EXCRETION OF TRICHLOROETHYLENE AFTER INHALATION BY HUMAN SUBJECTS
}

\author{
BY \\ V. BARTONÍČEK \\ From the Institute of Industrial Hygiene and Occupational Diseases, Prague
}

(RECEIVED FOR PUBLICATION APRIL 23, 1961)

\begin{abstract}
Eight volunteers were exposed to trichloroethylene vapour $(1,042 \mu \mathrm{g}$./1.) for five hours; 51 to $64 \%$ of the inhaled trichloroethylene was retained. The concentration of trichloroethanol and trichloroacetic acid in the urine was studied daily for a three-week period; on the third day both metabolites were determined in faeces, sweat, and saliva. The concentration of trichloroacetic acid in plasma and red blood cells was studied on alternate days. Of the trichloroethylene retained, 38.0 to $49.7 \%$ was excreted in the urine as trichloroethanol and 27.4 to $35.7 \%$ as trichloroacetic acid. Of both metabolites $8.4 \%$ was excreted in the faeces. Sweat collected on the third day of the experiment contained 0.10 to $1.92 \mathrm{mg} . / 100 \mathrm{ml}$. trichloroethanol and 0.15 to $0.35 \mathrm{mg} . / 100 \mathrm{ml}$. trichloroacetic acid. In saliva the concentrations were 0.09 to $0.32 \mathrm{mg}$. $/ 100 \mathrm{ml}$. trichloroethanol and 0.10 to $0.15 \mathrm{mg} . / 100 \mathrm{ml}$. trichloroacetic acid. The value of the expression trichloroethanol/ trichloroacetic acid calculated in the urine within 22 days was within the range $1 \cdot 15$ to $1 \cdot 81$.
\end{abstract}

The importance of trichloroethylene to industry and the frequent occurrence of acute and chronic poisoning by this solvent led to the following studies in animals and man.

It is well known that those exposed to trichloroethylene (TRI) excrete an insignificant amount of free TRI, a greater amount of monochloroacetic acid, and a considerable amount of trichloroethanol (TCE) and trichloroacetic acid (TCA) in the urine.

Opinions on the mechanism of the toxic effect of TRI vary considerably. It is not yet known which metabolite is responsible for its toxicity. Comparison of $L^{2} D_{50}$ in animals shows the order of toxicity to be: (1) Monochloroacetic acid (inhibitor of different enzyme systems); (2) TCE (powerful narcotic); (3) free TRI, and (4) TCA which is one order less toxic than TCE.

Much work has been done on the excretion of TCE and TCA. Free TRI has been repeatedly determined in expired air. Little is known of TRI metabolism in man. Studies on the metabolites of TRI in plasma and blood cells have not been extensive. Little is known of other possible means of excretion, e.g. faeces. Sweat, saliva, and tears have not been studied hitherto.

Although the amount of TRI metabolites excreted by routes other than the urine may be considered negligible, to us this small amount was found significant in accounting for that percentage of TRI for which there was no satisfactory explanation in our balance experiments. Analyses, therefore, of blood, sweat, saliva, and faeces, in addition to urine and expired air, in subjects exposed to a single inhalation of TRI in an exposure chamber were undertaken.

Preparatory to this study experiments were carried out on the quantitative conditions for excretion of both the main metabolites of TRI in rabbit urine and a simultaneous comparison of the different metabolic balance in rabbits and man (Bartoníček and Souček, 1959).

\section{Methods}

Apparatus.-The exposure chamber consisted of a brick-built room $9 \cdot 1 \mathrm{~m}^{3}$ hermetically sealed by a double door and ventilated by a constant air flow.

The required concentration of TRI in the chamber was obtained by an apparatus consisting of a 10-1. mixing flask containing TRI, two flowmeters, and a cylinder of compressed air (Teisinger and Souček, 1948). Both flowmeters were equipped with suitable capillary tubes and the air flow controlled by the level of water column 
in the parallel branch. Air samples were taken half, one and a half, two and a half, three and a half, and four and a half hours from the beginning of exposure. The concentration in the chamber was kept at about $1,000 \mu \mathrm{g}$. TRI/litre. Air samples were taken from the air chamber by an igelite tube, the mouth of which was attached at head level. The dead space of the tube was removed before the suction of the sample into an evacuated glass cylinder (volume 0.51 .), the sample was then cooled in a refrigerator at $0^{\circ} \mathrm{C}$., filled with $10 \mathrm{ml}$. chilled pyridine, and shaken for five minutes in an electric shaker. The content of TRI in the aliquot was determined by the method described by Souček and Franková (1952).

The apparatus for expired air consisted of a 10-l. flask and a gas-meter. The subject expired air through a glass mouth-piece and igelite tube into the mixing flask for exactly five minutes. The air was then led through an igelite tube into the gas-meter which measured the pulmonary volume at rest. The air sample from the flask was obtained by the technique described above.

The absolute amount of retained TRI was calculated from the following formulae valid for a five-hour exposure:

$$
\begin{aligned}
& M=K R P \times 300, \\
& R_{i}=100\left(K_{i}-K_{e}\right) / K_{i}
\end{aligned}
$$

$\mathbf{M}=$ TRI retained $(\mu \mathrm{g}$.$) .$

$\mathrm{K}=$ average concentration of TRI in chamber ( $\mu \mathrm{g} . / \mathrm{l}$.).

$\mathbf{R}=$ fraction of TRI retained. $R_{i}=\%$ TRI retained.

$\mathbf{P}=$ pulmonary volume at rest in litres per minute.

$K_{i}=$ concentration of TRI in inspired air $(\mu \mathrm{g} . / 1$.).

$\mathrm{K}_{\mathrm{e}}=$ concentration of TRI in expired air ( $\left.\mu \mathrm{g} . / \mathrm{l}.\right)$.

Volunteers.-Nine healthy normal subjects, four men and five women (between 19 and 57 years of age), were exposed. Daily records were kept of diet, drinks, unexpected events such as illness etc. Two of them had been given ethanol (50 to 70 g.) per os on certain days during the experiment. Urine collection was taken 24 hours after entering exposure chamber; there was no collection during exposure which lasted for five hours. (The subjects were not allowed to pass urine during the exposure.)

\section{Determination of Metabolites.}

Urine.-This was collected within 24 hours and kept in a cool place or refrigerator until measured. TCE colorimetrically determined in $\mathbf{0 . 2} \mathrm{ml}$. sample (Vlachová, 1957). TCA colorimetrically determined in $2 \mathrm{ml}$. sample (Souček and Franková, 1952). Calibration curves linear in both with maximal absorption at 5,100 $\AA$.

Blood.-Samples were taken in the morning from a cubital vein on the second to the fifth day and every alternate day as required, i.e. samples from each subject 10 to 14 times in a three-week period. Blood, $5 \mathrm{ml}$., was mixed with three drops $4 \%$ isotonic solution of heparin and centrifuged for 10 minutes. Plasma was carefully removed from the mass of erythrocytes. Plasma and blood cells were treated for the determination of TCA by the method of Souček (1959). Erythrocytes were washed free of plasma, suspended in physiological solution, stored for four hours at $4^{\circ} \mathrm{C}$., stirred occasionally, centrifuged for 10 minutes, and TCA determined in the supernatant.*

Faeces.-10 g. stool were dispersed in $40 \mathrm{ml}$. physiological solution. Suspension was removed by vacuum filtration. The total of both metabolites in an aliquot of the filtrate was determined (Vlachová, 1957). TCA alone was difficult to determine as the filtrate was often coloured by bile pigments.

Sweat and Saliva.-The subject was weighed to the nearest $50 \mathrm{~g}$. and put into a sleeping bag on a sofa in the air-conditioned exposure room. Both arms were put into igelite bags reaching to and fixed at the shoulder. Shortly before beginning the experiment the subject was injected subcutaneously with $0 \cdot 1 \mathrm{ml} .1 \%$ pilocarpine hydrochloride per $10 \mathrm{~kg}$. body weight. In 10 to 20 minutes there was profuse sweating, salivation, and lachrymation. A total of $10 \mathrm{ml}$. saliva was collected, and an aliquot of this determined for TCE and TCA by the method described above. Hot tea, 300 g., was given half an hour after the injection. The sweat experiment lasted one and a half hours, and then the subject was weighed again. Drops of sweat were collected from the igelite bags, measured, and analysed by the method described above.

Expired Air.-The subject expired air into a bubble flask equipped with a frit and filled with chilled physiological solution. The air from this was let into the gasmeter which measured $10 \mathrm{l}$. air. An aliquot was pipetted from the physiological solution and both metabolites determined by the method described above.

\section{Results}

Tables 2 to 7 show the levels of TCE and TCA in different biological media on the third day of the experiment. Figs. 1 to 3 show the levels of these metabolites in urine and of TCA in plasma and blood cells. Figs. 1 and 2 show that the curve of excretion of TCE is exponential. The level of TCE in urine reaches a considerable height within 24 hours on the day following exposure. On the following days it decreases rapidly until on the last days it reaches zero. The curve of TCA increases from initial lower values to a maximum on the third or fourth day. Then it drops gradually and reaches a level similar to that of TCE. The ratio of both metabolites in urine (TCE/TCA) during the 22 days' experiment is given in Table 8 .

Tables 4, 5, 6, and 7 show the other ways by which both metabolites are excreted. A certain amount is

\footnotetext{
*The absorption curve of the Fujiwara reaction in the erythrocyte eluate had two maximum points: the first was found on the invisible part of the spectrum (maximum below $4,000 \AA$ ) and could not be determined accurately by our photo-colorimeter. We believe it belonged to TRI. The second was found at 5,100 $\AA$, in agreement with maximum absorption of the colour complex for TCA as registered by our apparatus. (In this respect we have not distinguished between TCA and chloral hydrate.)
} 
TABLE 1

PHYSIOLOGICAL PARAMETERS OF SUBJECTS, PERCENTAGE AND ABSOLUTE AMOUNT OF TRI RETAINED IN THE ORGANISM, AND PERCENTAGE OF TRI EXCRETED IN FORM OF TCE AND TCA IN URINE

\begin{tabular}{|c|c|c|c|c|c|c|c|}
\hline \multirow{2}{*}{ Subject } & \multirow{2}{*}{$\begin{array}{c}\text { Air Intake at } \\
\text { Rest } \\
\text { (1. } / \mathrm{min} .)\end{array}$} & \multicolumn{2}{|c|}{ TRI Retained } & \multirow{2}{*}{$\begin{array}{c}\text { 24-hour Urine } \\
\text { Volume } \\
\text { (litre) }\end{array}$} & \multicolumn{3}{|c|}{ Percentage of TRI Excreted As } \\
\hline & & (mg.) & ( $\%$ intake) & & TCE & TCA & $\mathbf{T C A}+\mathbf{T C E}$ \\
\hline $\begin{array}{l}\text { V.F. } \\
\text { D.V. } \\
\text { P.H. } \\
\text { K.M. } \\
\text { Z.H. } \\
\text { H.D. } \\
\text { J.V. } \\
\text { V.K. } \\
\text { R.E.* }\end{array}$ & $\begin{array}{l}6 \cdot 5 \\
7 \cdot 2 \\
7 \cdot 1 \\
5 \cdot 6 \\
5 \cdot 5 \\
6 \cdot 0 \\
7 \cdot 1 \\
5 \cdot 4 \\
6 \cdot 0\end{array}$ & $\begin{array}{r}1,010 \\
1,057 \\
1,370 \\
1,080 \\
891 \\
874 \\
1,266 \\
979 \\
1,170\end{array}$ & $\begin{array}{l}54 \\
51 \\
64 \\
64 \\
60 \\
54 \\
58 \\
59 \\
57\end{array}$ & $\begin{array}{l}0.97 \\
0.78 \\
1.59 \\
1.01 \\
1.00 \\
0.93 \\
1.05 \\
0.76 \\
1.26\end{array}$ & $\begin{array}{l}42.6 \\
48.4 \\
38.0 \\
44.4 \\
43.9 \\
49.7 \\
49.6 \\
46.4\end{array}$ & $\begin{array}{l}35 \cdot 7 \\
27 \cdot 9 \\
33 \cdot 0 \\
36 \cdot 4 \\
29 \cdot 6 \\
27 \cdot 4 \\
32 \cdot 8 \\
32 \cdot 8\end{array}$ & $\begin{array}{l}78 \cdot 3 \\
76 \cdot 3 \\
71 \cdot 0 \\
80 \cdot 0 \\
73 \cdot 5 \\
77 \cdot 1 \\
82 \cdot 4 \\
79 \cdot 2\end{array}$ \\
\hline Mean values & $6 \cdot 3$ & 1,066 & 58 & 1.01 & $45 \cdot 4$ & 31.9 & $77 \cdot 3$ \\
\hline
\end{tabular}

*The faeces and sweat only were examined. Data of this subject have not been included in calculating the mean values of this Table.

TABLE 2

QUANTITY OF TCE AND TCA AND THE RATIO TCE : TCA OF 24-HOUR URINE SAMPLE COLLECTED ON THIRD DAY OF EXPERIMENT

\begin{tabular}{|c|c|c|c|c|c|}
\hline Subject & $\begin{array}{l}\text { TRI Retained } \\
\text { (mg.) }\end{array}$ & $\begin{array}{c}\text { TCE } \\
\text { (mg./100 ml.) }\end{array}$ & $\begin{array}{c}\text { TCA } \\
\text { (mg./100 ml.) }\end{array}$ & $\begin{array}{l}\text { TCE + TCA } \\
\text { (mg./100 ml.) }\end{array}$ & TCE : TCA \\
\hline $\begin{array}{l}\text { V.F. } \\
\text { D.V. } \\
\text { H.D. } \\
\text { Z.H. } \\
\text { P.H. } \\
\text { K.M. } \\
\text { V.K. } \\
\text { J.V. }\end{array}$ & $\begin{array}{r}1,010 \\
1,057 \\
874 \\
891 \\
1,370 \\
1,080 \\
979 \\
1,266\end{array}$ & $\begin{array}{r}6 \cdot 3 \\
10 \cdot 1 \\
18.9 \\
7 \cdot 9 \\
5 \cdot 1 \\
11.4 \\
15.2 \\
9.5\end{array}$ & $\begin{array}{r}6.6 \\
10.4 \\
8.4 \\
23.5 \\
4.9 \\
19.2 \\
6.0 \\
8.7\end{array}$ & $\begin{array}{l}12.9 \\
20 \cdot 5 \\
27 \cdot 3 \\
31 \cdot 4 \\
10 \cdot 0 \\
30 \cdot 6 \\
21 \cdot 2 \\
18 \cdot 2\end{array}$ & $\begin{array}{l}0.96 \\
0.98 \\
2.25 \\
0.33 \\
1.05 \\
0.59 \\
2.56 \\
1.08\end{array}$ \\
\hline Mean values & 1,066 & $10 \cdot 6$ & $11 \cdot 0$ & $21 \cdot 5$ & $1 \cdot 23$ \\
\hline
\end{tabular}

TABLE 3

TCA CONCENTRATION OF PLASMA (mg./100 ml. PLASMA) AND RED CELLS (mg./100 ml. RED CELL MASS) ON THIRD DAY AFTER EXPOSURE TO TRI

\begin{tabular}{|c|c|c|c|c|c|c|}
\hline \multirow{2}{*}{ Subject } & \multirow{2}{*}{$\begin{array}{c}\text { TRI Retained } \\
\text { (mg.) }\end{array}$} & \multicolumn{5}{|c|}{ TCA Concentration in Blood } \\
\hline & & Plasma & R.B.C. & $\underset{\text { Plasma }}{\text { Maximum Val }}$ & es in & Plasma : R.B.C. \\
\hline $\begin{array}{l}\text { V.F. } \\
\text { D.V. } \\
\text { H.D. } \\
\text { Z.H. } \\
\text { P.H. } \\
\text { K.M. } \\
\text { V.K. } \\
\text { J.V. }\end{array}$ & $\begin{array}{r}1,010 \\
1,057 \\
874 \\
891 \\
1,370 \\
1,080 \\
979 \\
1,266\end{array}$ & $\begin{array}{l}4 \cdot 0 \\
3 \cdot 3 \\
3 \cdot 3 \\
2 \cdot 4 \\
1 \cdot 5 \\
0 \cdot 9 \\
1 \cdot 8 \\
1 \cdot 7\end{array}$ & $\begin{array}{l}1.0 \\
0.8 \\
0.5 \\
0.4 \\
0.3 \\
0.3 \\
0.4 \\
0.4\end{array}$ & $\begin{array}{l}\text { 2nd to 3rd day } \\
\text { 2nd day } \\
\text { 3rd day } \\
\text { 2nd day } \\
\text { 2nd day } \\
\text { 5th day } \\
\text { 2nd to 4th day } \\
\text { 4th day }\end{array}$ & $\begin{array}{l}4 \cdot 0 \\
2 \cdot 7 \\
2 \cdot 1 \\
2 \cdot 5 \\
1 \cdot 8\end{array}$ & $\begin{array}{l}4 \cdot 0 \\
4 \cdot 1 \\
6 \cdot 6 \\
6 \cdot 0 \\
5 \cdot 0 \\
3 \cdot 0 \\
4 \cdot 5 \\
4 \cdot 3\end{array}$ \\
\hline Mean values & 1,066 & $2 \cdot 4$ & 0.5 & & & $4 \cdot 8$ \\
\hline
\end{tabular}

excreted by the faeces (Table 4 ), and the values vary over a small range. On the seventh day of exposure no trace of either substance was found in three subjects. The sum only of these metabolites was determined in the faeces (vide methods). Because of the composition of the experimental group (two men and five women) $100 \mathrm{~g}$. of faeces was taken as an average value of the daily excreted amount.

Several small temporary peaks were observed on the excretion curve of TCE in volunteers V.F. and D.V. (Figs. 1 and 2) who had been given ethanol to drink the previous day. None of the other volunteers showed any effect from the ingestion of food and drink.

\section{Discussion}

Instead of successive exposures for several days we gave a single exposure of five hours at a concentration high enough to follow the excretion of TCE and TCA for at least three weeks after exposure. The concentration we used is much higher than the 
TABLE 4

SUM OF TCE AND TCA IN THE FAECES (mg./100 g.) OF SUBJECTS ON THIRD AND SEVENTH DAY AFTER EXPOSURE TO TRI

\begin{tabular}{|c|c|c|c|}
\hline \multirow{2}{*}{ Subject } & \multirow{2}{*}{$\begin{array}{c}\text { TRI Retained } \\
\text { (mg.) }\end{array}$} & \multicolumn{2}{|c|}{$\begin{array}{c}\text { Metabolites in Faeces } \\
\text { (mg./100g.) }\end{array}$} \\
\hline & & $\begin{array}{c}\text { Third Day } \\
\text { (TCE }+ \text { TCA) }\end{array}$ & $\begin{array}{l}\text { Seventh Day } \\
\text { (TCE + TCA) }\end{array}$ \\
\hline $\begin{array}{l}\text { V.F. } \\
\text { D.V. } \\
\text { H.D. } \\
\text { Z.H. } \\
\text { P.H. } \\
\text { J.V. } \\
\text { R.E. }\end{array}$ & $\begin{array}{r}1,010 \\
1,057 \\
874 \\
891 \\
1,370 \\
1,266 \\
1,280\end{array}$ & $\begin{array}{c}18 \cdot 3-19 \cdot 6 \\
16 \cdot 6-18 \cdot 0 \\
7 \cdot 7-8 \cdot 4 \\
18 \cdot 3-19 \cdot 6 \\
15 \cdot 4-16 \cdot 8 \\
18 \cdot 5-19 \cdot 8 \\
24 \cdot 8-27 \cdot 0\end{array}$ & $\begin{array}{l}0 \\
0 \\
0\end{array}$ \\
\hline Mean values & 1,107 & $17 \cdot 1-18 \cdot 5$ & \\
\hline
\end{tabular}

permitted standard for Czechoslovakia which is 400 $\mu \mathrm{g} . / 1$. Values higher than $1,000 \mu \mathrm{g}$./l. are found, both in our factories and abroad (Cotter, 1950; Kleinfeld and Tabershaw, 1954; Bardoděj and Krivucová, 1955a; Berka and Vyskočil, 1955; Straus, Wilkinson, Wurm, and Harrold, 1956; Savičevič and KendaJeličič, 1957). We believe the single high concentration which we used to be completely harmless.

A summary of the significant data is given in Table 1.

The percentage of retained TRI, 51 to $64 \%$, average $58 \%$ at an average concentration of $1,042 \mu \mathrm{g} . / 1$., is in agreement with the findings of Souček, Teisinger, and Pavelková (1952), who give 56 to $60 \%$ (average concentration $850 \mu \mathrm{g} . / 1$.$) and Souček and Vlachová$
TABLE 5

TCE AND TCA EXCRETED IN URINE AND FAECES (mg./24 hours) ON THIRD DAY AFTER EXPOSURE TO TRI

\begin{tabular}{|c|c|c|c|c|}
\hline \multirow{2}{*}{ Subject } & \multicolumn{4}{|c|}{ TCE + TCA (mg./24 hours) } \\
\hline & Faeces & Urine & Total & $\%$ in Faeces \\
\hline $\begin{array}{l}\text { V.F. } \\
\text { D.V. } \\
\text { H.D. } \\
\text { Z.H. } \\
\text { P.H. } \\
\text { J.V. }\end{array}$ & $\begin{array}{c}18 \cdot 5-19 \cdot 8 \\
16 \cdot 6-18 \cdot 0 \\
7 \cdot 7-8 \cdot 4 \\
18 \cdot 3 \cdot 19 \cdot 6 \\
15 \cdot 4 \cdot 16 \cdot 8 \\
18 \cdot 5-19 \cdot 8\end{array}$ & $\begin{array}{l}147.0 \\
162.0 \\
211.0 \\
160.1 \\
168.0 \\
162.0\end{array}$ & $\begin{array}{l}166 \cdot 2 \\
179 \cdot 3 \\
218 \cdot 1 \\
179 \cdot 1 \\
18.1 \\
281 \cdot 2\end{array}$ & $\begin{array}{r}11 \cdot 6 \\
9.6 \\
3.7 \\
10 \cdot 1 \\
8.7 \\
6.8\end{array}$ \\
\hline Mean values & $15 \cdot 8-17 \cdot 0$ & $185 \cdot 0$ & $201 \cdot 3$ & 8.4 \\
\hline
\end{tabular}

(1960) who give 58 to $70 \%$ (average concentration $615 \mu \mathrm{g} . / 1$.$) .$

The percentage of TRI excreted as TCA in the urine varies widely: in rats by inhalation 1.2 to $7.8 \%$ (Forssmann and Holmquist, 1953); in dogs under TRI anaesthesia 5 to $8 \%$ (Barrett, Cunningham, and Johnston, 1939); in rabbits intramuscularly, less than $1 \%$ (Bartoníček and Souček, 1959); in man 6 to $16 \%$ (Ahlmark and Forssman, 1951); 5 to $8 \%$ (Bardoděj and Krivucová, 1955b); 13\% (Grandjean, Münchinger, Turrian, Haas, Knoepfel, and Rosenmund, 1955); 7 to $27 \%$ (Souček et al., 1952); 10 to $30 \%$ (Souček and Vlachová, 1960). We found 27.4 to $35.7 \%$ (average $31.9 \%$ ) which is consistent with the upper limits found by Souček and Vlachová (1960). The differences are probably related to (1) the duration of the observations, (2) differences in the concentrations of TRI, and (3) considerable

TABLE 6

EXCRETION OF TCE AND TCA IN SWEAT ON THIRD DAY AFTER EXPOSURE TO TRI

\begin{tabular}{|c|c|c|c|c|c|c|}
\hline \multirow{2}{*}{ Subject } & \multirow{2}{*}{$\underset{\text { (mg.) }}{\text { TRI Retained }}$} & \multirow{2}{*}{$\begin{array}{l}\text { Sweat Produced } \\
(\mathrm{g} .)\end{array}$} & \multicolumn{2}{|c|}{ Metabolites (mg./100 ml.) } & \multirow{2}{*}{$\underset{(\mathrm{mg} .)}{\mathrm{TCE}+\mathrm{TCA}}$} & \multirow{2}{*}{ TCE/TCA } \\
\hline & & & TCE & TCA & & \\
\hline $\begin{array}{l}\text { V.F. } \\
\text { D.V. } \\
\text { H.D. } \\
\text { Z.H. } \\
\text { P.H. } \\
\text { R.E. }\end{array}$ & $\begin{array}{r}1,010 \\
1,057 \\
874 \\
891 \\
1,370 \\
1,280\end{array}$ & $\begin{array}{l}180 \\
350 \\
160 \\
420 \\
650 \\
310\end{array}$ & $\begin{array}{l}0.87 \\
1.56 \\
1.42 \\
1.92 \\
0.37 \\
0.10\end{array}$ & $\begin{array}{l}0.15 \\
0.20 \\
0.35 \\
0.20 \\
0.30 \\
0.20\end{array}$ & $\begin{array}{l}1.8 \\
6.1 \\
2.8 \\
8.9 \\
4.3 \\
1.0\end{array}$ & $\begin{array}{l}5.8 \\
7.8 \\
4.1 \\
9.6 \\
1.2 \\
0.5\end{array}$ \\
\hline Mean values & 1,080 & 345 & 1.04 & 0.23 & $4 \cdot 2$ & $4 \cdot 8$ \\
\hline
\end{tabular}

TABLE 7

EXCRETION OF TCE AND TCA IN SALIVA ON THIRD DAY AFTER EXPOSURE TO TRI

\begin{tabular}{|c|c|c|c|c|c|}
\hline \multirow{2}{*}{ Subject } & \multirow{2}{*}{$\begin{array}{l}\text { TRI Retained } \\
\text { (mg.) }\end{array}$} & \multicolumn{4}{|c|}{ Metabolites in Saliva $(\mathrm{mg} . / 100 \mathrm{ml}$.) } \\
\hline & & TCE & TCA & Total & TCE : TCA \\
\hline $\begin{array}{l}\text { V.F. } \\
\text { D.V. } \\
\text { H.D. } \\
\text { Z.H. } \\
\text { P.H. } \\
\text { R.E. }\end{array}$ & $\begin{array}{r}1,010 \\
1,057 \\
874 \\
891 \\
1,370 \\
1,280\end{array}$ & $\begin{array}{l}0.15 \\
0.14 \\
0.09 \\
0.10 \\
0.32 \\
0.09\end{array}$ & $\begin{array}{l}0 \cdot 10 \\
0 \cdot 15 \\
0 \cdot 10 \\
0 \cdot 10 \\
0 \cdot 15 \\
0 \cdot 10\end{array}$ & $\begin{array}{l}0.25 \\
0.29 \\
0.19 \\
0.20 \\
0.47 \\
0.19\end{array}$ & $\begin{array}{l}1.50 \\
0.93 \\
0.90 \\
1.00 \\
2.13 \\
0.90\end{array}$ \\
\hline Mean values & 1,080 & $0 \cdot 15$ & $0 \cdot 12$ & $0 \cdot 27$ & $1 \cdot 23$ \\
\hline
\end{tabular}




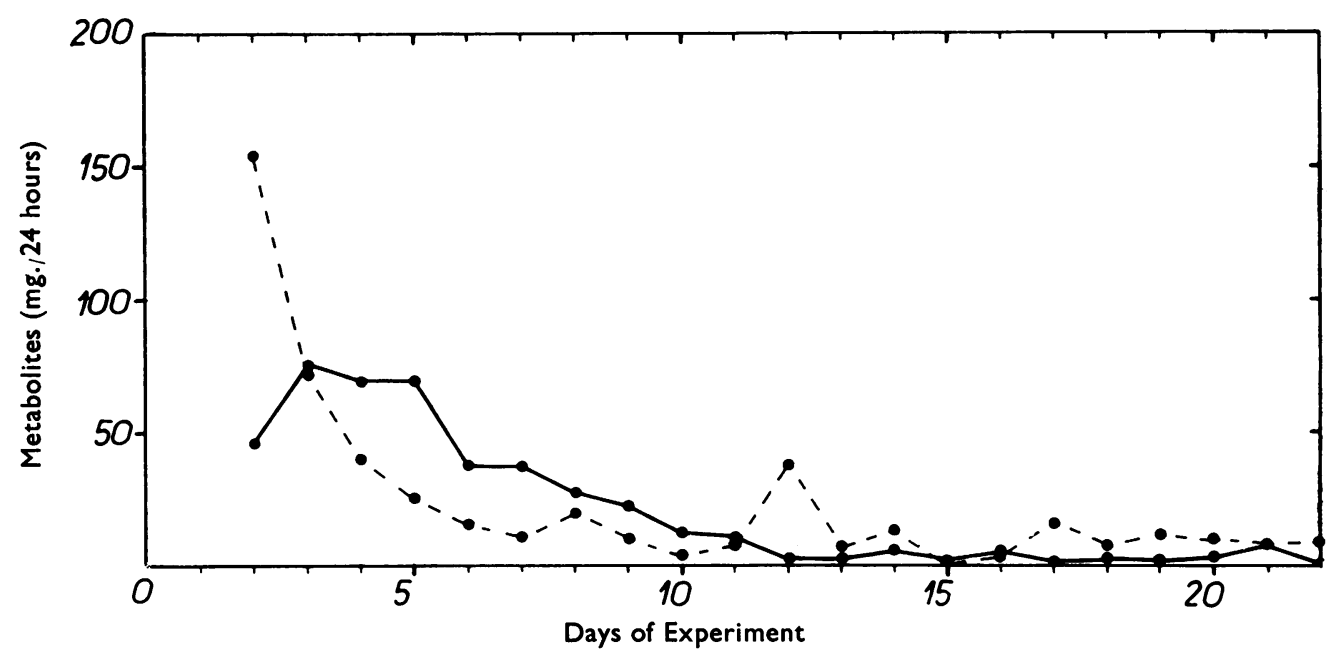

FIG. 1.-Values of TCE and TCA in urine of V.F. Abscissa: days of experiment. Ordinate: amount of metabolites (mg. in 24 hours). On the 11th, 13th, 16th days ethanol was drunk. ... TCE -

individual variation in percentage of TRI metabolized as TCA. We are in agreement with other authors that during prolonged exposure the percentage of TRI metabolized to TCA decreases.

Table 1 shows 38.0 to $49.7 \%$ (average $45.4 \%$ ) of TRI excreted as TCE. Figs. 1 and 2 show excretion curves of TCE and TCA. Souček and Vlachová (1960) give 32 to $59 \%$ TCE excreted in urine at an average concentration of $615 \mu \mathrm{g}$./litre. Their excretion curves are in agreement with ours. The effect of ingested ethanol is marked and will be the subject of another paper (Bartoníček, 1962).

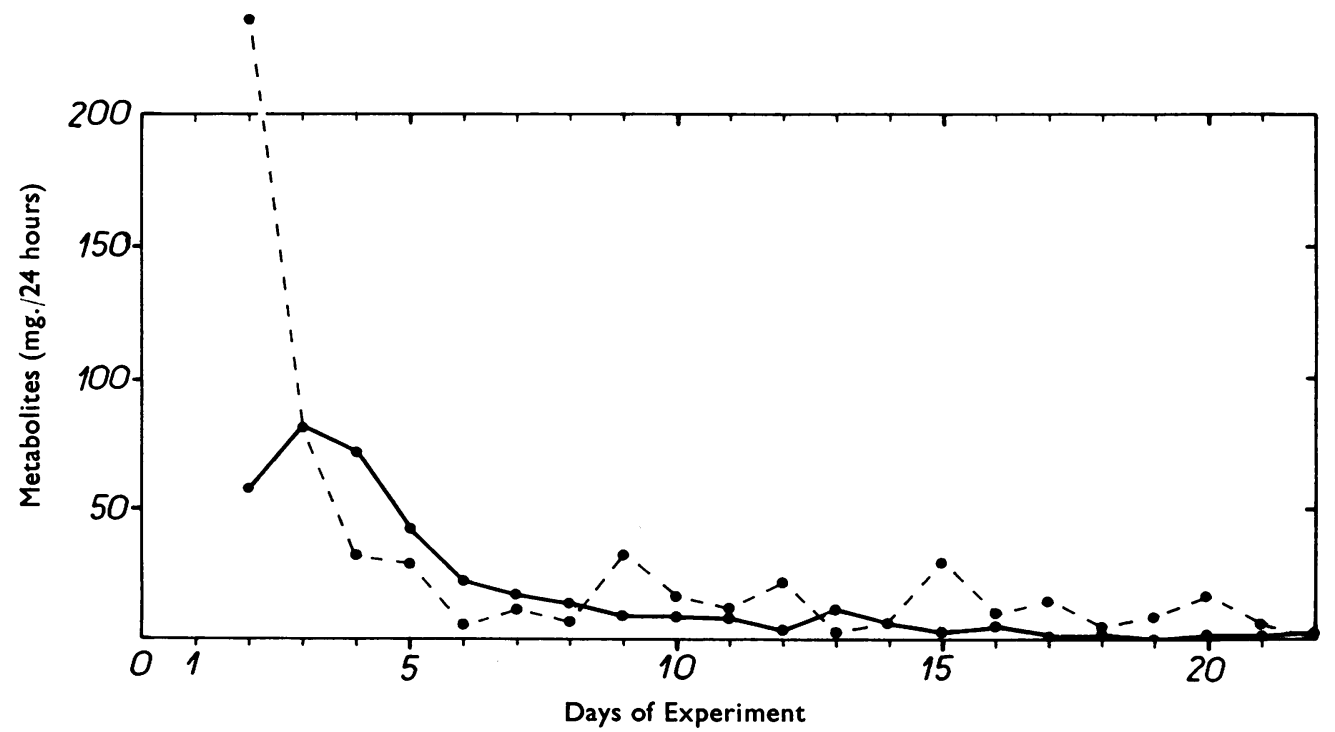

FIG. 2.-Similarly for urine of D.V. Ethanol was drunk on 8th, 11th 16th days. $\ldots$. TCE - TCA. 


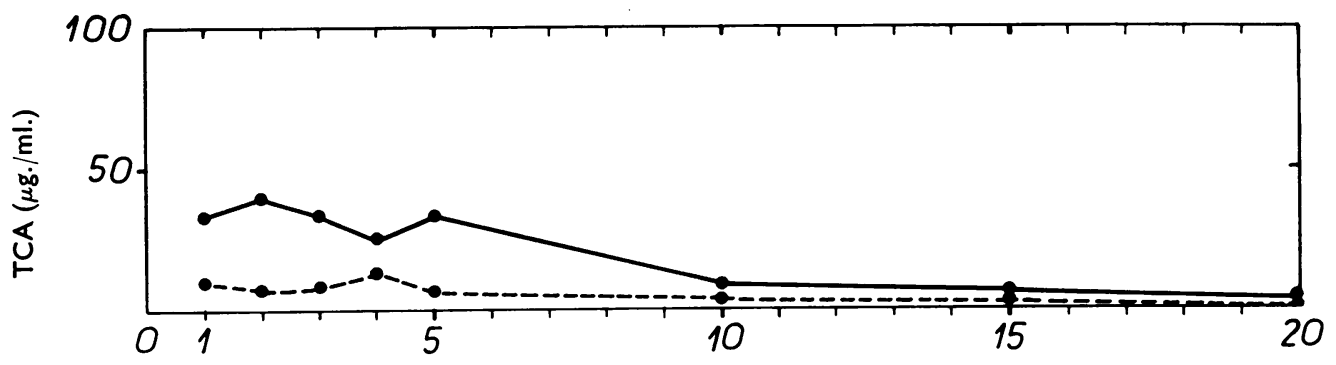

Days after Exposure

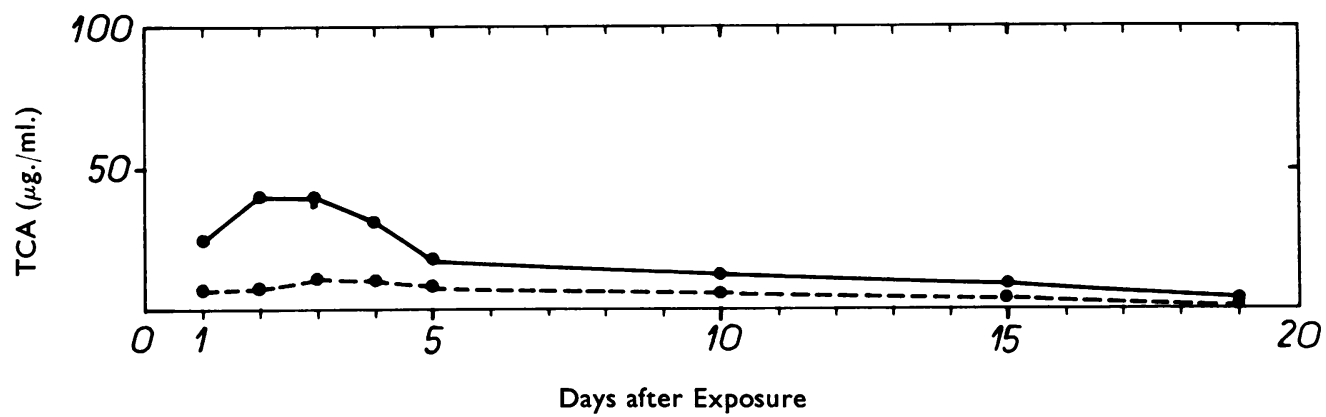

Fig. 3.-The TCA levels ( $\mu$ g. $/ \mathrm{ml}$.) in the plasma and RBC of two subjects followed for 20 days after exposure to TRI. plasma $\ldots .-$. RBC

The ratio TCE/TCA varies widely because the curves of excretion of both converge and cross in the first two to four days after exposure and thus depend on the moment when the determination of long-term excretion is carried out. We found a mean value of 1.44 (Table 8).

Bardoděj and Krivucová (1958) obtained a ratio of 1.99 when the concentration of TRI in the air was 0.3 to $0.6 \mathrm{mg}$./litre. Medek (1958) obtained 1.25 to 4.07 (average 1.84) at a concentration of 0.4 mg./litre. Souček and Vlachová (1960) found the ratio $2 \cdot 4$. Small differences in the data of authors

TABLE 8

RATIO TCE : TCA EXCRETED IN URINE DURING A 22 DAY PERIOD OF OBSERVATION AFTER A SINGLE EXPOSURE TO TRI

\begin{tabular}{c|c}
\hline Subject & TCE : TCA \\
\hline V.F. & 1.20 \\
D.V. & 1.72 \\
P.H. & $1 \cdot 15$ \\
K.M. & 1.22 \\
Z.H. & 1.49 \\
H.D. & 1.81 \\
V.V. & 1.52 \\
V.K. & 1.42 \\
\hline Mean value & 1.44 \\
\hline
\end{tabular}

mentioned above and our results may be explained by the duration of the experiment. TCA is on the average excreted for a longer time than TCE, which explains the lower average value TCE/TCA in our results which were undertaken over a longer period.

Souček (1954) showed that methods used hitherto for the determination of TCA in plasma are unreliable because TCA is, in these conditions, adsorbed on the proteins in a varying degree. Powell (1945) carried out the determination of TCA in blood for the first time. After complete TRI narcosis she found the curve of TCA in blood rose

TABLE 9

RATIO OF TCA CONCENTRATION IN URINE AND PLASMA ON THIRD DAY AFTER EXPOSURE TO TRI

\begin{tabular}{c|c|c|c}
\hline \multirow{2}{*}{ Subject } & \multicolumn{2}{|c|}{ TCA (mg./100 ml.) } & $\begin{array}{c}\text { Ratio } \\
\text { Urine : Plasma }\end{array}$ \\
\cline { 2 - 3 } & Urine & Plasma & Ur. \\
\cline { 2 - 3 } V.F. & 6.3 & 4.0 & 1.6 \\
D.v. & 10.1 & 3.3 & 3.1 \\
H.D. & 18.9 & 3.3 & 5.7 \\
Z.H. & 7.9 & 2.4 & 3.3 \\
P.H. & 5.1 & 1.5 & 3.4 \\
K.M. & 11.4 & 1.1 & 10.2 \\
V.K. & 15.2 & 1.8 & 8.4 \\
J.V. & 9.5 & 1.7 & 5.6 \\
\hline Mean values & 10.6 & 2.4 & 5.2 \\
\hline
\end{tabular}


for $\mathbf{4 8}$ hours and then gradually dropped or remained for several days on a plateau and then gradually dropped. The daily excretion of TCA in the urine ran practically parallel. Abrahamsen (1957) examining blood and urine after peroral poisoning concluded that TRI was deposited in the organs and released in part into the blood where it was oxidized to TCA and excreted in the urine. The presence of TCA for a long time, in this case for 27 days, in serum and urine, seems to confirm his conclusion.

Paykoç and Powell (1945) believe that TCA does not penetrate erythrocytes. They did not study the possibility of TCA adsorption on the surface of blood cells, which amounts to 2,000 to 3,000 sq. m. in the total blood volume of man. TCA at higher concentrations readily denatures proteins but acts differently at lower concentrations. We have no further data of the formation of TCA bonds on plasma proteins at concentrations of the order of $10^{-5} \mathrm{~g}$. $/ \mathrm{ml}$. used in our experiments. The bond may be chemical, reversible or irreversible, or physical, i.e. adsorption. Similarly, where TCA fixation on the surface of the erythrocyte is concerned, dilution or emulsification in the semi-liquid surface membrane must be considered. From the following data we believe this to be a question of adsorption. Table 3 shows that plasma contains 3 to 6.6 times more TCA than do blood cells. Comparison of TCA concentrations in urine and plasma is shown in Table 9.

The TCA urine/TCA plasma ratio of 5.2 is in agreement with Powell (1945). We also agree with her that TCA does not penetrate the erythrocyte membrane. No trace of TCA was found in our solution of haemoglobin. TCA is probably adsorbed on the surface of blood cells and can be washed off almost quantitatively in a four-hour elution and determined in the eluate. It is not a question of traces of TCA in the thin film of plasma adhering mechanically to the surface of blood cells even after separation by centrifuge. It is a question of the different amount of TCA found in plasma and on blood cells and of the different curves of these values (Fig. 3). Powell (1945) studied TCA levels for seven to 12 days in the blood of four patients after much greater exposure. The trends of both curves, concentrations 0.3 to $5.5 \mathrm{mg} . / 100 \mathrm{ml}$. and maxima occurring on the second to fourth day, agree with our findings. There are very few data on the behaviour and course of TCE in blood and plasma after TRI inhalation. Butler (1949) found a small amount of free TCE (up to $3 \mathrm{mg}$. $/ 100 \mathrm{ml}$.) in the plasma of dogs and a greater amount of TCEglucuronide. We found both metabolites in faeces, sweat, and saliva. The samples were taken on the third day after exposure to TRI and TCA excretion was at its maximum. The comparison of concentra- tions of TCA + TCE in urine and faeces is interesting. Urine values are 10.0 to 31.4 (average $21.5 \mathrm{mg}$./100 ml.) (Table 2); faeces 7.7 to 27.0 (average 17.8 mg./100 ml.) (Table 4). The values are practically the same. This means that both metabolites pass into the digestive system through bile (Owens and Marshall, 1955) and saliva, are secreted by liver cells and the salivary gland cells, reaching concentrations only somewhat lower than those of urine. This can be explained by the resorption of water from the primary bile in the gall-bladder and from the intestinal content of the colon. The daily excretion of faeces in man is $\mathbf{1 0}$ times less than that of urine and thus the excretion of the TRI metabolites in faeces is less significant (Table 5). On the third day after exposure to TRI the amount in faeces was $8.4 \%$, in urine $91.6 \%$. Ahlmark and Forssman (1951) found $8 \%$ of the total of excreted TCA in the faeces of rats.

Our findings and those of Owens and Marshall (1955) are in conflict with the opinion of Paykoç and Powell (1945) that TCA does not penetrate the body cells and circulates only in the extracellular fluid.

Excretion of TCE and TCA in sweat is not significant, but it does show that TCE-glucuronide circulating in blood and TCA present in blood in ion form as water soluble substances can pass into the parenchyma of sweat glands. We cannot, however, a priori, exclude the non-physiological action of pilocarpine which we used and which has a marked vagotropic action.

Table 6 shows that the amount of TCE is higher than TCA in sweat as well as in urine. The values of TCA are steady whereas the values of TCE vary widely. Table 7 shows the excretion of the metabolites in saliva to be negligible. Saliva is swallowed and the metabolites pass into the faeces. They enter the gland parenchyma from the blood and are not confined to the extracellular fluid.

Comparison of air samples with those of other biological material was carried out on the fourth day of the experiment. TRI is expired mainly on the first and second days or in traces on the third day. In the determination of TCE the presence of TRI made no difference. TCE was not found in the expired air on the fourth day. [Souček and Vlachová (1955) have described the variable occurrence of a small amount of chloroform in expired air and believe that it may arise from splitting of TCA or from chloral hydrate.]

I wish to express my thanks to Professor J. Teisinger for his support and interest, to Dr. B. Souček for critical comments and review of the study, and to Mrs. Rosa Ehrmann for her technical assistance. 


\section{REFERENCES}

Abrahamsen, A. M. (1957). Scand. J. clin. Lab. Invest., 9, 406.

Ahlmark, A., and Forssman, S. (1951). Acta physiol. scand., 22, 326. Bardoděj, Z., and Krivucová, M. (1955a). Cs. Epidem., 4, 90.

-, - (1955b). Pracov. Lék., 7, 217.

- , (1958). Čs. Hyg., 3, 268.

H. M., Cunningham, J. G., and Johnston, J. H. (1939). J. industr. Hyg., 21, 479.

Bartonícek, V. (1962). Arch. environm, Hlth. In the press.

-, and Soucek, B. (1959). Arch. Gewerbepath. Gewerbehyg., 17

Berka, I., and Vyskocil, J. (1955). Thomayerova Sbirka, Vol. 344, Státní zdrav. nakladatelství, Prague.

Butler, T. C. (1949). J. Pharmacol. exp. Ther., 97, 84

Cotter, L. H. (1950). Arch. industr. Hyg., 1, 319.

Forssmann, S., and Holmquist, C. E. (1953). Acta pharmacol (Kbh.), 9,235

Grandjean, E., Münchinger, R., Turrian, V., Haas, P. A., Knoepfel, H.-K., and Rosenmund, H. (1955). Brit. J. industr. Med., 12, 131 .
Kleinfeld, M., and Tabershaw, I. R. (1954). Arch. industr. Hyg., 10, 134.

Medek, V. (1958). Pracov. Lék., 10, 135.

Owens, A. H., and Marshall, E. K. (1955). Bull. Johns Hopk. Hosp., 97, 320. Paykoç, Ż. V., and Powell, J. F. (1945). J. Pharmacol. exp. Ther., 85,

Powell, J. F. (1945). Brit. J. industr. Med., 2, 142.

Savičevic, M., and Kenda-Jelicič, D. (1957). Papers on XIIth Int. Congress of Occupational Medicine in Helsinki.

Soucek, B. (1954). Pracov. Lék., 6, 277.

(1959). Method for the determination of trichloracetic acid in plasma. Unpublished communication. plasma. Unpublished communication. 404

—, Teisinger, J., and Pavelková, E. (1952). ibid., 4, 31.

, Teisinger, J., and Pavelková, E. (1952).

—, and Vlachová, D. (1955). ibid., 7, 143. 60.

Straus, R., Wilkinson, A., Wurm, M., and Harrold, B. D. (1956) Industr. Med. Surg., 25, 151.

Teisinger, J., and Souček, B. (1948). Cas. Lék. čes., 87, 933.

Vlachová, D. (1957). J. Hyg. Epidem. (Praha), 1, 225.

\section{THE JANUARY (1962) ISSUE}

The January (1962) issue contains the following papers:-

The Size of Cotton Dust Particles Causing Byssinosis: An Environmental and Physiological Study. C. B. McKerrow, S. A. Roach, J. C. Gilson, and R. S. F. Schilling

Byssinosis: The Acute Effect on Ventilatory Capacity of Dusts in Cotton Ginneries, Cotton, Sisal, and Jute Mills. J. C. Gilson, H. Stott, B. E. C. Hopwood, S. A. Roach, C. B. McKerrow, and R. S. F. Schilling

The Pharmacological Activity of Extracts of Cotton Dust. Anne Davenport and W. D. M. Paton

Some Pharmacological Actions of Cotton Dust and Other Vegetable Dusts. P. J. Nicholls

Contact Eczema Caused by True Teak (Tectona Grandis). H. K. Krogh

A Swiss Manufacturer Sees the Industrial Revolution in England. Heinrich Buess

The Attack Rate of Progressive Massive Fibrosis. A. L. Cochrane

Ventilatory Capacity in Miners. A Five-year Follow-up Study. I. T. T. Higgins and P. D. Oldham

Miscellanea

Obituary

Book Reviews

A number of copies are still available and may be obtained from the Publishing Manager, British Medical Association, Tavistock Square, W.C.1, price 17s. $6 d$. 